\title{
Anna Zalewska*
}

Uniwersytet Marii Curie-Skłodowskiej

\section{PROSPOŁECZNA, PARTYCYPACYJNA I „WSPÓLNOTOWA” ARCHEOLOGIA BLISKIEJ PRZESZŁOŚCI JAKO SPOSÓB NA NADAWANIE SENSU TRWANIU (LUDZI I RZECZY) ORAZ JAKO ANTIDOTUM NA NIEDOSTATKI WIEDZY I TRYWIALIZACJĘ PRZESZŁOŚCI}

We run afoul of things when we assume a demarcated, disconnected past as the ontological starting point for what we do in the present. Archaeology does not discover the past as it was; archaeologists work with what has become of what was; what was, as it is always becoming.

(Olsen, Shanks, Webmoor i Witmore 2012: 6)

There is a widespread belief that the kind of collaborative research fostered by community archaeology will be crucial if archaeology is to have a future.

(Marshall 2002: 218)

\begin{abstract}
W celu ukazania specyfiki i wartości archeologii bliskiej przeszłości wskazane zostały w niniejszym artykule pola, w których archeologia w naturalny sposób łączy się z refleksją antropologiczną i socjologiczną. Obok uwag odnoszących się do kwestii powiązań ludzi i rzeczy oraz zależności ludzi od rzeczy, przedstawione zostały argumenty na rzecz tezy, że archeologia (jako dostarczająca wiedzy „źródłowej” dyscyplina naukowa i jako rodzaj działań społeczno-kulturowych, potencjalnie pomocnych w nawiązywaniu i pogłębianiu wartościowych więzi społecznych/wspólnotowych), jest fundamentalnie związana z teraźniejszością. Jako inspirująca w kontekście określania i kreowania relacji społeczeństwa z archeologią wskazana została tzw. archeologia wspólnotowa (community archaeology), zaś jako egzemplifikacja założeń teoretycznych zaprezentowany został autorski program Przydrożne Lekcje Historii (pomocny w dowiedzeniu społecznej użyteczności i sprawczości materialnych pozostałości przeszłości oraz archeologii). W podsumowaniu przedstawiono argumenty za zasadnością traktowania jako integralnego elementu praktyki archeologicznej społecznego obiegu wiedzy archeologicznej, który autorka proponuje nazywać procesem uspołeczniania archeologii.
\end{abstract}

Słowa kluczowe: proces uspołeczniania archeologii, społeczny obieg wiedzy archeologicznej, archeologia bliskiej przeszłości, archeologia wspólnotowa

* Adres do korespondencji: Anna Zalewska, Instytut Archeologii, Uniwersytet Marii Curie-Skłodowskiej, pl. M. Curie-Skłodowskiej 5, 20-031 Lublin, e-mail: azalew@op.pl. 


\section{WPROWADZENIE}

Narasta paląca, poznawcza i społeczna potrzeba poważniejszego poddania refleksji specyfiki, znaczeń i wartości materialnych pozostałości przeszłości, w tym rzeczy związanych z nieodległą w czasie przeszłością, które stopniowo, choć nie bez oporów, stają się przedmiotem badań archeologii. Znaczenia tych pozostałości unaoczniają się między innymi w wyniku dążeń do uzyskania niedostępnej już w żaden inny sposób wiedzy szczegółowej na temat niektórych aspektów minionych wydarzeń (w tym dwudziestowiecznych). Równie istotny jest udział materialnych pozostałości w procesach upamiętniania i zapominania, utrwalania i zacierania, troski i deprecjonowania, uwznioślania i trywializacji tego, co choć minione wciąż rzutuje na tu i teraz. Skłania to do wnikliwszego przyjrzenia się istocie procesu społecznego obiegu wiedzy archeologicznej (tj. procesu uspołeczniania archeologii). Na proces ten składają się wszelkie przejawy aktywacji rzeczy zakorzenionych w przeszłości oraz wiedzy z nimi związanej, tj. wiedzy o relacjach ludzi i rzeczy dawniej i dzisiaj, o specyfice trwania w czasie, rozkładu i nakładania się na siebie materialnych pozostałości aktywności ludzkiej oraz, co dla mnie kluczowe, o zależności od rzeczy naszej wiedzy o ludziach. Wyniki tego typu obserwacji mogą się przyczynić do takiego ukierunkowywania archeologii, by mogła ona działać jako potencjalne antidotum zarówno na brak czy niedostatek informacji o niektórych, często kluczowych, wydarzeniach i zjawiskach z nieodległej przeszłości, jak i na ignorowanie, pomijanie czy niszczenie powiązanych z nimi rzeczy.

Celem niniejszego artykułu jest refleksja nad potencjałem, znaczeniem, rolami oraz wartościami towarzyszącymi materialnym pozostałościom bliskiej przeszłości. Uznanie, że o bliskości tych pozostałości przesądza jedynie relatywnie nieodległy w czasie kontekst ich zaistnienia byłoby jednak uproszczeniem. Może to być warunek istotny, ale nigdy nie jedyny i wystarczający. O bliskości wiązanych z przeszłością materialnych mediów/nośników informacji, pamięci, emocji przesądza skuteczność procesu nadawania im znaczeń i istotności w teraźniejszości. W tym sensie jako bliższe mogą być traktowane te znaleziska, które są czynne społecznie, mają znaczenie i odgrywają istotne role - niezależnie od momentu ich zaistnienia (czy to w bardzo odległej, czy w bliskiej przeszłości). Idąc tym tropem, jako przedmiot badań archeologii bliskiej przeszłości, (po)traktowane być mogą te zagadnienia, które odnoszą się do nadawania sensu archeologii oraz materialnym pozostałościom z przeszłości reaktywowanym we współczesności. Ich charakterystykę rozpoczynam w niniejszym artykule od kilku dość oczywistych uwag z zakresu ogólnej teorii archeologii, również z myślą o potencjalnym czytelniku o innym niż archeologiczne wykształceniu. Przez krytyczną analizę zależności naszej wiedzy o ludziach od rzeczy staram się dowieść, że archeologia (którą, co jeszcze raz pragnę podkreślić, postrzegam zarówno jako dostarczającą wiedzy ,źródłowej” dyscyplinę naukowa, jak i jako rodzaj działań społeczno-kulturowych, potencjalnie pomocnych w nawiązywaniu i pogłębianiu wartościowych więzi społecznych/wspólnotowych) w naturalny sposób łączy się między innymi z refleksją antropologiczną i socjologiczną.

Za godne uwagi i pilnej pogłębionej refleksji, z którą archeolog samotnie poradzi sobie w sposób ograniczony, warto uznać aktualne przekształcanie dotychczasowych odbiorców wiedzy archeologicznej w aktywnych „uczestników” zdarzeń kulturowych ${ }^{1}$. Następnie

1 O specyfice i zakresie archeologii współczesności w naszym kraju, niestety zbyt często zazębiającej się $\mathrm{z}$ domeną „,czarnej archeologii” (przejawiającej się zainteresowaniem detektorystów materialnymi reliktami 
Prospołeczna, partycypacyjna i „wspólnotowa” archeologia bliskiej przeszłości...

przedstawiam argumenty przemawiające za uznaniem wartości archeologii bliskiej przeszłości (do której tylko poniekąd przystają funkcjonujące już w dyskursie naukowym określenia takie jak archeologia współczesnej przeszłości, archeologia historyczna czy archeologia nas (por. Schiffer, Gould 1981; Buchli i Lucas 2001)) za praktykę społeczną fundamentalnie związaną z teraźniejszością. Jako inspirującą w kontekście relacji społeczeństwa z archeologią (czyli między innymi z wynikami badań i ze znaleziskami pozyskiwanymi z udziałem archeologii i funkcjonującymi w przestrzeni społecznej) uznaję kształtującą się aktualnie silnie socjologizującą teorię i praktykę tzw. archeologii wspólnotowej (community archaeology), stąd pomysł, by nakreślić tu jej założenia metodologiczne i postulować aplikację jej dyrektyw również w polskim kontekście.

W kolejnej części artykułu, w celu zobrazowania zasygnalizowanych zagadnień teoretycznych, przywołane zostały dwa konkretne konteksty funkcjonowania materialnych pozostałości użycia broni chemicznej, a szerzej konfliktu zbrojnego o stuletniej metryce. Konfrontacja dziś radykalnie odmiennych kontekstów funkcjonowania pozostałości z lat 1914 i 1915 roku, tj. z czasów Wielkiej Wojny z okolic Bolimowa (Mazowsze, Polska) i z okolic Ypres (Flandria, Belgia), unaocznia fakt, że ich relatywna bliskość znacząco się różni. W pierwszym wypadku wynika ona jedynie z kryterium chronologicznego; natomiast w drugim (obok z punktu widzenia archeologa ich „młodej” metryki) na ich bliskość składają się aktualne procesy społeczne, w tym aktywność na polu archeologii - pogłębiające więzi teraźniejszości z przeszłością.

W podsumowaniu odnoszę się do konieczności potraktowania jako integralnego i mieszczącego się w „naukowych ramach” czwartego (o czym poniżej) elementu praktyki archeologicznej czyli społecznego obiegu wiedzy archeologicznej. Z uwagi na bieżące przemiany społeczne oraz rosnącą „,antropologizację” i „socjologizację” myślenia archeologicznego konieczne jest zwrócenie uwagi na tę domenę jako na szczególnie pomocną w uzmysławianiu sobie, że archeolodzy nie są już jedynymi podmiotami sprawczymi we wspólnocie interpretacyjnej i komunikacyjnej, w której funkcjonują zarówno oni, jak i relikty przeszłości, oraz że ich działalność poznawcza kreuje kontekst kulturowo-społeczny i zarazem jest przez ten kontekst kreowana.

\section{NASZA ZALEŻNOŚĆ OD RZECZY, W TYM ZALEŻNOŚĆ OD RZECZY NASZEJ WIEDZY O LUDZIACH}

Bardziej lub mniej dla nas zrozumiałe materialne pozostałości z przeszłości stawiają nas zarówno wobec wielkiego ,zlepku” współistniejących horyzontów temporalnych, jak i wobec dylematów natury poznawczej, etycznej i moralnej. W procesie poznawczym, niemal każdorazowo, zmuszeni jesteśmy odnosić się do sieci powiązań pomiędzy różnymi punktami w czasie,

I czy II wojny światowej) decydują aktualnie, w dużej mierze, raczej amatorzy niż profesjonalni archeolodzy. Intencjonalne, nieprofesjonalne ingerencje w ziemię, motywowane chęcią wydobycia z niej reliktów przeszłości - w sytuacjach, które nie są następstwem decyzji archeologów - są przejawem (samo)woli „uczestników” interakcji z tymi reliktami. Stanowi to poniekąd wynik nienadążania akademików za poszerzającą się, często wbrew ich woli, przestrzenią prób. Wątek ten rozwijam w Zalewska $2013 \mathrm{a}$. 
między różnymi racjami oraz biografiami ludzi, rzeczy i miejsc, które nie tylko przeplatają się ze sobą, łącząc również w sensie materialnym różne przeszłości i teraźniejszości, ale też, ze względu na samą swą „naturę" $\mathrm{i}$ trwałość, sięgają przed siebie w stronę przyszłości (vide González-Ruibal 2008: 250-251; Olsen 2010: 107 i nast.).

Zależność naszej wiedzy o ludziach od rzeczy wydaje się szczególnie znacząca (wyrazista) w kontekście nakładania się dwóch aspektów bliskości, czyli w odniesieniu do materialnych pozostałości wydarzeń nieodległych w czasie (na przykład „wieku wojen”, czyli XX wieku), które jednocześnie są lub mogą być reaktywowane jako sprawcze społecznie $\mathrm{w}$ teraźniejszości przez co stają się potencjalnie istotne w przyszłości. Aktualnie archeologia ma lub może mieć udział w nadawaniu istotności również tym rzeczom, których istnienie zainicjowane zostało w nieodległej przeszłości. Atutem archeologii jest aparat poznawczy pozwalający na wnikliwe diagnozy odnoszące się do relacji ludzi i rzeczy oraz do rzeczy samych w sobie ( $w$ tym do przenikających się naturalnych $i$ antropogenicznych uwarunkowań ich zaistnienia i stopniowego rozkładu, a także do określenia potencjału ich trwania w przyszłości). Konieczność uwrażliwienia na złożoność świata, w którym krzyżują się losy podmiotów ludzkich i innych, ściśle zespala myślenie o i w archeologii z refleksją antropologiczna, socjologiczną, kulturoznawcza, filozoficzną, a także ze studiami nad pamięcią. Zakładam, że (współ)działanie reprezentantów tych dyscyplin jest niezbędne w dążeniach do zrozumienia (a przynajmniej do ogarnięcia wyobraźnią) przeszłości. Przejawia się ona w rzeczach i przez rzeczy. Natomiast nasze reakcje na materialne pozostałości z przeszłości i nasze decyzje w stosunku do nich, na równi z informacjami, jakie pozostałości te w sobie zawierają, mogą być pomocne w lepszym rozumieniu teraźniejszości.

W sytuacji gdy połączenia między dyscyplinami badawczymi tak rzadko są wykorzystywane (zwłaszcza aktywna troska o ściślejsze powiązanie archeologii i socjologii na gruncie nauki polskiej wydaje się kwestią przyszłości), poddaję pod dyskusję założenie, że materialne pozostałości bliskiej przyszłości i rozgrywające się z ich udziałem (lub wbrew nim) procesy poznawania i upamiętniania (oraz ignorowania i zapominania) mogą stanowić poznawczo obiecujący i społecznie istotny przedmiot badań wielodyscyplinarnych oraz podwalinę dla działań wspólnotowych. Aktywność na tym polu wydaje się z wielu powodów uzasadniona, a nawet jak sądzę niezbędna. Jednym z nich jest fakt, że na naszych oczach, ale tylko poniekąd z naszym udziałem, dochodzi aktualnie do radykalnych przewartościowań ${ }^{2}$. Z dotychczas dominującej pozycji biernego obserwatora, „uczestnik” poszukiwań, zarówno ten zaproszony przez archeologa do współpracy, jak i ten działający samowolnie, przekształca się w rozszerzający sferę swoich doznań „podmiot zaangażowany”3.

\footnotetext{
2 Niektóre z tych przewartościowań odnoszą się wprost do archeologii i to właśnie one, stanowiąc tu pole egzemplifikacji, zostaną poddane refleksji, choć zdaję sobie sprawę, że zagadnienie partycypacji i problem wspólnoty daleko przekracza ramy podjętych w niniejszym artykule kwestii.

3 „Przemiana” z tradycyjnego odbiorcy w uczestnika, współtwórcę wydarzenia dokonuje się dzięki jego zaangażowaniu w działania poznawcze. Poruszane są wówczas takie sfery doznań podmiotu jak pragnienia, wyobrażenia i wrażliwość. Są to „najbardziej na serio brane elementy osobowości człowieka, dla niego rzeczywiste i autentyczne” (Pałubicka 2013: 199-200). Ten ,przeżyciowo-emocjonalny” czy zmysłowy charakter partycypacji był dotychczas wielokrotnie rozważany między innymi w kontekście „interaktywności i multimedialności”, „wizualności” czy „performatywności” współczesnej kultury (por. Szpociński 2009; Pałubicka 2013).
} 
O ile działania wbrew przyjętym zasadom i prawu (przejawiające się np. w „czarnej archeologii”) budzą uzasadniony niepokój, o tyle za krzepiące uznać należy pozytywne przejawy tych przewartościowań jak np.:

- wspólnotowe badania wykopaliskowe;

- opiekę społeczności lokalnych nad stanowiskami archeologicznymi po zakończeniu badań;

- czynienie ze stanowiska archeologicznego istotnego społecznie elementu lokalnej tożsamości;

- okołoarcheologiczne działania edukacyjne i rozrywkowe (czy też ich połączenie tzw. edutainment) itp.

Zawierają one w sobie potencjał poszerzania sfery przeżyć „uczestników” (również niearcheologów) przez wywołanie nowych, często zaskakujących doświadczeń i emocji ${ }^{4}$. Skłania to do postrzegania materialnych reliktów przeszłości (które często, choć nie zawsze stanowią przedmiot poznawczy archeologii) oraz przyczyn i następstw naszych interakcji z nimi jako istotnych elementów procesu kształtowania szeroko rozumianej rzeczywistości społecznej. Jest to szczególnie czytelne w procesie kształtowaniu stosunku do trudnego i bolesnego dziedzictwa, które pośrednio ${ }^{5}$ jest determinowane przez materialne pozostałości konfliktów zbrojnych i innych dramatów, które rozegrały się na terenie dzisiejszej Polski w XX wieku.

Nie chodzi mi jednak o to, by dociec tego, jak ,skuteczniej” za pośrednictwem archeologii, epatować materialnym wymiarem dramatów (na przykład widokiem przestrzelonych czaszek czy masowością rzeczy z dołów śmierci lub z linii frontu), a wraz z nimi bólem, rozterką i tragedią historii, które rozegrały się na naszych ziemiach. Byłby to, w mojej opinii, przejaw braku szacunku dla tych, którzy osobiście znaleźli się w zasięgu minionych wydarzeń oraz pożywka dla niestosownego „sensacjonizmu”. Taka postawa uzasadniałaby określanie aktualnych przemian w przestrzeni archeologii polskiej mianem li tylko „,boomu na archeologię martyrologiczną"6, z czym radykalnie się nie zgadzam.

To nie boom, a więc kompulsywna, chwilowa hossa pewnej problematyki, która nagle i doraźnie skupia uwagę społeczeństwa, ale konsekwentna i wieloletnia praktyka badawcza. W Polsce trwa ona od ponad dwóch dekad w odniesieniu do archeologii martyrologii czy archeologii zbrodni, zaś od pięciu dekad w odniesieniu do archeologii pól bitewnych. W toku realizacji ich celów (praktycznych i poznawczych) stopniowo zmienia się (pogłębia?) poczucie bliskości przeszłości i teraźniejszości oraz świadomość i wrażliwość historyczna. W niektórych wypadkach towarzyszy temu zainteresowanie (a nawet fascynacja) trwaniem rzeczy w czasie.

\footnotetext{
4 Czy jednak, jak twierdzi Anna Pałubicka, „oddziaływanie na sferę emocji człowieka” przesądza o „,aintelektualnym charakterze odbioru"? Odpowiedź na to pytanie wydaje się szczególnie wiążąca w kontekście archeologii bliskiej przeszłości, dlatego postaram się na nie odpowiedzieć w ostatniej części artykułu.

5 Sygnalizowana tu pośredniość wynika z postrzegania dziedzictwa nie substancjalnie, ale jako zjawiska konstruowanego społecznie.

${ }^{6}$ Boom na archeologie martyrologicznq (za IAR 20.09.2013 vide http://tvp.info/informacje/nauka/boom-na-archeologie-martyrologiczna/12459840).
} 


\section{POTENCJAŁ ARCHEOLOGII W KSZTAŁTOWANIU RZECZYWISTOŚCI SPOŁECZNEJ}

Określając społeczny potencjał archeologii, nie chodzi o to, by obrawszy „dystans ironisty", za wszelką cenę dążyć do nomograficznych odpowiedzi na pytania o typy odniesień materialnych pozostałości do konkretnych kontekstów społeczno-kulturowych oraz o ich użytek w procesie komunikacji kulturowej. Choć i tego typu próby (zdeterminowane, jak mi się aktualnie wydaje i czego wciąż nie potrafię wyeliminować z własnych badań, bardziej przez wstępny zamysł badawczy, „wiedzę pozaźródłową”, potrzeby i postawę interpretatora, czyli przez tzw. przesądy, niż przez specyfikę znaczących rzeczy samych w sobie) coś jednak do archeologii wnieść mogą. Chodzi raczej o to, by z udziałem rzeczy związanych z bliską przeszlością (zarówno tych zaświadczających o eskalacji wojen i terroru wieku XX, jak również tych, które zbliżają nas do zrozumienia banalnej codzienności, a przez to do złożoności czasów minionych w całej ich rozciąglości) uchronić przeszłość, zarówno tę bliską, jak i chronologicznie odległą, przed trywializacją. Pośrednio będzie to chroniło nas samych przed miałkością i powierzchownością oglądu rzeczywistości, w której żyjemy.

Misja archeologii, zwłaszcza w odniesieniu do najbliższej przeszłości, nie opierałaby się wyłącznie, a nawet nie przede wszystkim, na generowaniu kolejnych opisów, dostarczaniu kolejnych danych czy przedstawianiu kolejnych interpretacji. Wobec ogromu zniszczeń i bólu, które przyniosły ze sobą porażki naszych współczesności, bardziej niż wyjaśnienia potrzebujemy obecnie „swoistego objawienia” zauważa Alfredo González-Ruibal (2008: 251). Zasadne wydaje się przywołanie tu również opinii pionierów archeologii współczesności i archeologii nas, w świetle których - ponieważ archeologia bada to, co „niewypowiedziane” i „nieukonstytuowane”, co leży poza granicami dyskursu, ponieważ obraca się w kontekście traumy, zniszczenia i bólu, wojen, reżimów totalitarnych, inżynierii społecznej - jej wyjątkowa rola jest nie do podważenia (Buchli i Lucas 2001, szersze omówienie vide Zalewska 2003).

Wyjątkowość archeologii wynika zarówno z jej możliwości w zakresie refleksji nad świadczącymi o minionych zdarzeniach rzeczami samymi w sobie, jak i z jej poważnego, wręcz kluczowego dla archeologów, stosunku do „kontekstów stratygraficznych”, w których rzeczy te zalegają. Jednocześnie, za równie istotne, co analizowanie kontekstów, w których rzeczy się znajdują i/lub są znajdowane ${ }^{7}$, należy uznać dostrzeganie znaczenia i specyfiki kontekstów ich odkrywania, tj. kontekstów w których funkcjonuje również wiedza archeologiczna. Dzięki dostrzeżeniu potencjału rzeczy oraz wyjątkowej informatywności kontekstów, w których rzeczy zalegają i/lub funkcjonują, archeologia jest w stanie aktywować wrażenie żywej obecności przeszlych wydarzeń oraz może być pomocna w nadawaniu sensu trwaniu przez czynienie przeszlości bliską. Należy przy tym podkreślić, że bliskość w czasie procesu pierwotnego, $\mathrm{z}$ którego materialnymi pozostałościami archeologia jako dyscyplina jest coraz intensywniej konfrontowana, wciąż w opinii niektórych archeologów przesądza o ich niearcheologicznym charakterze. Przyczyny tego są bardzo złożone.

Vide cenne uwagi m.in. P. Urbańczyka (2012: 433-448 i 2004) na temat znaczenia interpretacji sekwencji stratygraficznych jako podstawy samoidentyfikacji metodycznej archeologii i zwornika badań zarówno nad pojedynczymi zabytkami, jak i nad całym krajobrazem kulturowym. 
Za oczywiste i powszechnie akceptowalne uznawane jest natomiast to, co opisano niżej,

Jako proces pierwotny, rozumiany jest (I) proces społeczno-kulturowy, w którego efekcie powstały przedmioty i zmiany o antropogenicznym charakterze, których pozostałości badamy. Proces ten stanowi „właściwą” i „,podstawową” dziedzinę zainteresowań archeologa i przedmiot badań, którego dotyczą wydawane przez archeologa orzeczenia (za: Tabaczyński 1987). Natomiast procesy wtórne (do których odnoszę się w dalszej części artykułu) to procesy pochodne $\mathrm{w}$ stosunku do pierwotnego: (II) procesy stratyfikacji lub stratyfikacyjne (określane też jako procesy źródłotwórcze) - nieprzerwane od momentu depozycji do momentu ingerencji na przykład archeologa w daną strukturę stratygraficzna, a potem dalej trwające; (III) procesy poznawcze lub badawcze, obejmujące metody oraz cały zespół operatorów poznawczych, za pomocą których badacz formułuje problemy i stawia kolejne diagnozy, odkrywa, rejestruje oraz analizuje i interpretuje zachowane zespoły zabytkowe. Odnoszę się tu wprost (po drobnej korekcie polegającej na nadaniu procesom formy plural, która zdaje się pełniej oddawać ich specyfikę) do zastanej, trójczłonowej struktury, charakteryzującej kluczowe i integralnie związane z badawczą praktyką archeologiczną procesy/domeny I-III. Zostały one opisane w archeologicznym dyskursie polskojęzycznym i są konsekwentnie upowszechniane i doprecyzowywane, zwłaszcza przez nestora polskiej metodologii archeologii Stanisława Tabaczyńskiego (1987: 13, 43-48).

Jednocześnie jednak staram się wskazać i promować zasadność/konieczność (bardziej konsekwentnego i obligatoryjnego, niż to się dzieje dotychczas) poszerzenia tej wyżej wymienionej struktury procesu, która trafnie, acz niekompletnie, obrazuje fenomen archeologii, o czwartą domenę (domena IV). Proponuję dla niej nazwę: procesy uspoleczniania archeologii, są one tożsame ze społecznym obiegiem wiedzy o przeszłości kreowanej na podstawie jej materialnych pozostałości. $W$ ich zakres wliczam szczególnie interesujące, $w$ wielu wypadkach niepokojące przejawy procesów, które określam mianem podepozycyjnych (ich szczegółowe omówienie vide Zalewska w druku).

Mimo że domena ta jest bardzo istotna, to dotychczas zwłaszcza w metodologii polskiej była na ogół pomijana. Nie wykluczam, że jest to wynik postrzegania zawierających się w niej zagadnień przez badaczy przeszłości jako nienaukowych. Są jednak istotne powody, by z wynikającymi z tego typu postaw sądami polemizować.

\section{FUNDAMENTALNIE ARCHEOLOGICZNA TERAŹNIEJSZOŚĆ}

Archeologia (zwłaszcza archeologia teraźniejszości) „wysadza rygle czasu”, przyznając pewnym zdarzeniom z przeszłości wyjątkowy status bliskości. Bywa, że archeolodzy postuluja, aby archeologia zajmowała się wyłącznie przeszłością odległa, „czasem osnutym tajemnicą i niewiedzą" oraz że jeśli badane zjawiska odnoszą się do nieodległej przeszłości, to stanowią one domenę historii czy kryminologii, w kontekście których archeologia jest ,jedynie metodą pozyskiwania danych". Przywoływany jest argument, że do badania czasów, o których ,już wszystko wiemy” (na przykład historii XX wieku) archeologia „nie jest w stanie nic wnieść", zatem odkopywanie materialnych śladów wydarzeń z tego okresu 
jest li tylko metoda pozyskiwania danych i deprecjonuje ich archeologiczny charakter. Do nieadekwatności tego typu argumentacji można się odnieść zarówno w sensie przedmiotowym (przywołując liczne przykłady takich wydarzeń i zjawisk z bliskiej przeszłości odnośnie do których bez ingerencji archeologicznej nasza wiedza byłaby ułomna ${ }^{8}$ lub żadna9 ${ }^{9}$, jak i w sensie formalnym. Właśnie w sensie formalnym (tzn. dotyczącym logiki wywodu) archeologicznego charakteru materialnych pozostałości (tj. mediów i nośników informacji, wiedzy, znaczeń, emocji) nie powinien deprecjonować fakt ich ścisłej łączności z czasem i miejscem przedstawionym w przekazach pisanych (czyli z polem źródeł historycznych, które stanowią podstawę wnioskowania historyka), z polem danych kryminologicznych/sądowniczych (wnoszących informacje do śledztwa) czy z polem pamięci żywej(,biograficznej”).

Jednocześnie faktem jest, że nie wszystko w kontekście badań materialnych reliktów bliskiej przeszłości uznać można za archeologiczne, nawet jeśli rozgrywa się to z udziałem archeologa. Jeśli bowiem archeolog nie zadaje pytań badawczych odnośnie do odnajdywanych „,danych”, to jego bierny udział w kontekście odkrycia przesądza o ich „,niearcheologicznym" charakterze. Jeśli jednak ingerencji archeologa w zastaną strukturę materialną towarzyszą pytania badawcze, a pozyskane w efekcie tej ingerencji przedmioty lub informacje niematerialne zostają uznane za dane, wówczas mamy do czynienia z archeologią sensu stricto. Dzieje się to niezależnie od bliskości w czasie momentu pierwotnej depozycji badanych szczątków ludzkich lub rzeczy. Wziąwszy pod uwagę kluczowe znaczenie stratygrafii dla archeologii, przyjąć należy, że jeśli badaniom towarzyszy dążenie do zrozumienia przyczyn i sposobów ukształtowania się zastanej struktury stanowiska, to niezależnie od oddalenia w czasie procesu pierwotnego (I) oraz od specyfiki procesów wtórnych (II-IV) mamy do czynienia z archeologią per se. Wciąż niestety diagnoza ta nawet wśród autorytetów w zakresie wiedzy stratygraficznej nie jest oczywista w kontekście archeologii polskiej.

Aktualnie jako szeroko rozumiane środowisko archeologiczne, zmagamy się z odpowiedzią na pytanie o to, czy zagadnienia odnoszace się do XIX i XX wieku można postrzegać jako archeologię. Jak często bywa w podobnych przypadkach, eksperci ciągle się zastanawiają nad zasadnością rozszerzenia dyscypliny na „nowe” domeny, w sytuacji, gdy są to pola już bardzo intensywnie eksploatowane i produkujące dane. W rzeczywistości od momentu gdy rozpoczęto systematyczne rejestrowanie danych archeologicznych, materialne pozostałości z okresów nowożytnych i współczesnych notorycznie pojawiały się w strukturze stanowisk archeologicznych. Można wręcz postawić tezę, że tym, czym były dla konstytuowania się archeologii średniowiecznej badania miejskie (wymuszone okolicznościami przyspieszonej

8 Na przykład jednym z aspektów badań archeologii konfliktu i pól bitewnych jest analiza indywidualnego użycia broni oraz związanych z nią elementów. Ten poziom precyzyjnej wiedzy daje nie tylko obraz taktyki i strategii zastosowanej na polu bitwy, ale pozwala również na poznanie roli jednostki (żołnierza), w tym jego codzienności i zadań specjalnych (Scott, McFeaters 2011: 104).

9 Gdy pod koniec lat 80. XX wieku mogło wreszcie ujawnić się w pełni ogromne zapotrzebowanie społeczne na wiedzę o zbrodni katyńskiej, to właśnie archeolodzy „byli jedynymi ludźmi, którzy mogli dostarczyć obiektywnych faktów w tej sprawie" (A. Kola, Boom na archeologię martyrologiczna, za: IAR 20.09.2013 vide http://tvp.info/informacje/nauka/boom-na-archeologie-martyrologiczna/12459840; por. też Kola 2005). 
urbanizacji), tym dla konstytuowania się archeologii współczesności okażą się badania przedinwestycyjne. To w ich kontekście w sposób wręcz masowy unaoczniają się sytuacje, w których materialne pozostałości dwudziestowiecznych wydarzeń stanowią wymagającą zadokumentowania (a zatem interpretacji!) sekwencję archeologiczną, która naturalnie „dokłada się" do wszystkiego, co ją poprzedzało.

Tym samym również teraźniejszość staje się fundamentalnie archeologiczna, w takim samym stopniu, jak wszystkie inne okresy przeszłości i nie jest niczym innym jak przedłużeniem poprzedzającej ją historii. Warto zastanowić się nad propozycją odwrócenia standardowej propozycji postępowania archeologicznego, a mianowicie, by postrzegać jako istotne nie to, że niektóre z „miejsc aktualnych” (zawierających ślady zdarzeń z przeszłości ledwo minionej) mają korzenie archeologiczne, lecz to, że transformacje tych stanowisk w czasie okresów niedawnych nie moga być oddzielane od ich historii w skali długiego trwania (Olivier 2008: 89-90).

Unaocznienie fascynującej istoty transformacji i transgresji ludzi i rzeczy oraz ich przeszlego i teraźniejszego (!) wymiaru wraz z dowiedzeniem znaczenia bliskiej archeologii w nadawaniu sensu trwaniu (ludzi i rzeczy) wydaje się najistotniejszym zadaniem, z którym (z)mierzy się archeologia bliskiej przeszlości. Jednak nie jest to zadanie proste, gdyż poznanie broni się przed elementami społecznymi, ale nieudolnie, bo przez próby ich wykluczania.

\section{SPOŁECZNO-KULTUROWY WYMIAR POZNANIA: ARCHEOLOGIA WSPÓLNOTOWA (COMMUNITY ARCHAEOLOGY)}

Autonomiczność poznania uznaje się za wartość podstawową której spełnienie pozwala dopiero realizować inne. O poznaniu nieautonomicznym twierdzi się, że jest zanieczyszczone, splątane z elementami do poznania nienależącymi, a więc odbierającymi mu wiarygodność i racjonalny charakter" - diagnozuje Małgorzata Czarnocka (2007: 88). To pragnienie „autonomiczności” poznania wciąż przejawia się między innymi w dążeniu do osiągnięcia „perspektywy dystansu epistemologicznego” i postawy obserwatora niebędącego uczestnikiem wydarzeń, które poznaje, lecz pozostającego w „pozycji trzecioosobowej” (mającej ponadindywidualny, kulturowy i intersubiektywny status). Deprecjacja innych przekonań niż tych uznawanych za naukowe powoduje, iż refleksja nad nimi bywa ,wykluczona z obszaru nauki” (Pałubicka 2013: 175). Aktualnie jednak sytuacja zmienia się, a współczesne nurty przeciwstawiające się tezie o autonomiczności poznania są traktowane jako koncepcje socjologizujące (za: Czarnocka 2007: 88).

Nie podejmuję się tu rozstrzygania, czy zjawiska obserwowane aktualnie w szerokim polu archeologii bezdyskusyjnie uznać można za „socjologizujące”, ale postaram się wskazać niektóre zjawiska i opinie, w których zawierają się przejawy tej tendencji. Najbardziej wyrazista na tym polu wydaje się archeologia wspólnotowa (community archaeology), której celem jest umożliwienie współpracy z interesariuszami (z)aktywizowanymi wokół projektu archeologicznego, na wszystkich etapach „procesu poznawczego” (III). Z kolei to odgrywa 
znaczącą rolę w kontekście zrozumienia celów, uwarunkowań, specyfiki znalezisk i późniejszej prezentacji wyników badań (Tully 2007: 159), a zatem społecznego obiegu (cyrkulacji) wiedzy archeologicznej, w tym procesów podepozycyjnych (IV).

U podstaw archeologii wspólnotowej leży przeświadczenie, że naprawa archeologii jako takiej możliwa jest dzięki dopuszczeniu różnorodnych głosów do interpretacji przeszłości. Nie oznacza to bynajmniej rezygnacji z naukowego charakteru dociekań archeologicznych, lecz raczej jest to przejaw pogłębiającej się skłonności do dostrzegania związku pomiędzy badaniami a społeczeństwem oraz do traktowania wspólnot i jednostek (spoza archeologii) jako ,pomocnych w zmaganiach z dysproporcjami dominujących paradygmatów historycznych" (Tully 2007: 158). Pomimo tego, że część archeologów wydaje się wciąż nieprzygotowana do tego, by takie dictum zaakceptować, to jako coraz bardziej oczywiste jawi się to, że odkrycia archeologiczne mają istotne znaczenie w kontekście wielu sytuacji (tak społecznych, jak i politycznych), zaś sytuacje te silnie rzutują na te odkrycia. Dzieje się tak między innymi wówczas, gdy dane archeologiczne wykorzystywane są do legitymizacji, często opartych na nierówności i niesprawiedliwości, ideologii władzy (w której zawiera się potrzeba kontroli nad przeszłością) (por. Tilley 1989; Kobyliński 2009; Zalewska 2013b: 225-229).

Co jednak kluczowe i nowatorskie, archeologia wspólnotowa postrzegana jest jako mająca znaczenie dla procesu budowania spójności społecznej; na przykład w sytuacji gdy udaje się zbliżyć ze sobą mieszkańców współczesnych miast i wsi dzięki dzielonemu przez nich poczuciu własności lokalnego dziedzictwa kulturowego. W efekcie archeologii wspólnotowej przypisuje się sprawcza, rewoltująca, a nawet emancypacyjną rolę, która wykracza poza kontekst tubylczych, postkolonialnych czy mniejszościowych grup społecznych i dotyka wszelkiego rodzaju społeczności, w tym również grup z tzw. „pierwszego świata” i tych o zasięgu globalnym (Marshall 2002; Tully 2007).

Oceniając archeologię wspólnotową według kryterium jej (potencjalnego) wkładu w dzieje myśli archeologicznej, można stwierdzić, że jako najciekawsze jawi się podłoże opinii, iż ma ona nie tylko uzdrowić, ale i „utrzymać przy życiu” archeologię jako niezależną dyscyplinę. Wskazywany jest w tym kontekście między innymi fakt, że korzyści płynące z interakcji z archeologami i odnoszone przez społeczności lokalne są odwzajemniane i wpływają na poprawę archeologii przez wzajemną edukację. Edukacja ta staje się możliwa, gdy archeolodzy zdecydują się zmierzyć z ,alternatywnymi punktami widzenia”, co stanowi krok o kluczowym znaczeniu, jeśli archeologia jako dyscyplina naukowa ma mieć przed sobą jakąkolwiek przyszłość (Marshall 2002: 218). Ta diagnoza wydaje się szczególnie intrygująca w kontekście, w którym niewielu archeologów chce (lub może) w pełni angażować się w działania zdeterminowane /zdominowane aspektami prospołecznymi (,socjologizującymi”’). Sytuację taką obserwujemy aktualnie w Polsce ${ }^{10}$.

10 Choć nie sposób na razie w polskojęzycznym kontekście odnotować badań kompletnych (,siedmioskładnikowych" - o czym poniżej) w świetle metodologii proponowanej aktualnie dla community archaeology czy nawet w pełni zdeterminowanych przez formułę community archaeology, to działania prowadzące w kierunku bardziej systematycznego uspołeczniania archeologii coraz częściej postrzegane są jako istotne. 
Prospołeczna, partycypacyjna i „wspólnotowa” archeologia bliskiej przeszłości...

Tłumaczą ją poniekąd:

- tradycyjna tendencja do rozdzielenia „naukowego” podejścia do przeszłości (gdy przeszłość sama w sobie jest wystarczającym powodem, by się nią zajmować) od podejścia „praktycznego” (gdy materialne pozostałości przeszłości są badane, komentowane i wykorzystywane ze względu na bieżące potrzeby społeczne);

- brak odrębnych kadr i funduszy niezbędnych w podejmowaniu działań prowadzących do uspołeczniania i upublicznienia badań;

- niewygoda, utrudnienia, komplikacje i nieprzewidywalność (z)wiązane z angażowaniem „osób postronnych” w działania poznawcze;

- poczucie ryzyka, że wadliwa interakcja archeologów z ,amatorami” oraz tych drugich z materialnymi pozostałościami przeszłości może przyczynić się do niewłaściwego (po)traktowania substancji zabytkowej oraz że „nadmierne zbliżenie się” do ,amatorów” („wolontariuszy”) może zostać potraktowane przez „środowisko” jako lekkomyślność, koniunkturalizm czy nielojalność wobec racji zwolenników hermetycznego i ,autorytarnego" modelu archeologii.

Nie sposób przemilczeć tu faktu, że zasadna jest obawa, iż ze wzmożonym, bezpośrednim angażowaniem społeczeństwa do archeologii wiąże się ryzyko „efektów ubocznych” (Simpson 2008; Simpson i Williams 2008). Archeolodzy, decydując się na wdrażanie projektów formuły uspołeczniania archeologii (public lub community archaeology), muszą również mierzyć się z wyzwaniami natury etycznej, czyli w przypadku niepowodzenia „misji uspołeczniania” między innymi z narażaniem materialnych pozostałości z przeszłości na grabież, akty wandalizmu czy próby ich spieniężenia. Pomimo zagrożeń i wątpliwości, wciąż jednak rośnie przekonanie o wielości i zróżnicowaniu społecznych korzyści public/community archaeology. Wszelkie dążenia do osiągnięcia tych korzyści traktuje się jako „zasadne”, niezależnie od ewentualnego związanego z tym ryzyka (Little 2002). Podejmowane są też kroki mające na celu zoptymalizowanie działań w kręu community archaeology (dalej CA), czego przejawem jest między innymi poświęcone wyłącznie tej formie archeologii czasopismo (,Journal of Community Archaeology \& Heritage”), którego ambicją jest stworzenie „platformy dyskusji” dla wszystkich podejmujących tego typu działania oraz pola wymiany udanych i nieudanych doświadczeń w tym zakresie.

W opinii ,,archeologów wspólnotowych” obecnie nie przedstawiono jeszcze „oficjalnej” metodologii dla działań w ramach reprezentacji przeszłości, opartych na „wspólnotowej” współpracy. Jednak można już wyabstrahować pewne optymalne „wzorce działania”. Zdaniem Gemmy Tully (2007: 169) możliwe jest już określenie „silnej metodologicznej struktury bazowej" $\mathrm{CA}^{11}$.

11 W opinii G. Tully (2007) strukturę tę należy wciąż rozbudowywać w celu: ,przekazania większego zakresu uprawnień i własności zaangażowanym wspólnotom” i „poprawy jakości badań archeologicznych i muzeologicznych”. Bieżącym dążeniem CA jest stworzenie takiej metodologii, która będzie odpowiednia dla całej dyscypliny. Sprzyjać to ma „zdobyciu wreszcie szacunku i uznania” dla CA oraz bardziej wszechstronnemu jej wykorzystaniu. Dzięki bardziej holistycznemu podejściu, pomimo że wciąż niewystarczająco doceniana, CA może się okazać kluczowa w pogłębianiu „spójności w ramach wspólnot” (Wylie 1995: 271) 
Jako pomocne w uwolnieniu się od swoistego ,instynktownego” systemu stanowiącego podstawę praktyki archeologii wspólnotowej (diagnoza Tully 2007: 179) wskazuje się uznanie za niezbędne, kluczowe i nieredukowalne siedem podstawowych składników:

1) Odnosząca się do wszystkich etapów badań komunikacja i współpraca pomiędzy zespołem archeologicznym/muzeologicznym a społecznością lokalną.

2) Szkolenia, warsztaty i ochotnicze uczestnictwo mieszkańców we wszystkich obszarach projektu oraz zatrudnianie członków wspólnoty.

3) Publiczna prezentacja badań, postrzegana jako kluczowy element przekazywania informacji wspólnocie i innym osobom niebędącym członkami grup wspólnotowych.

4) Prowadzenie wywiadów (rejestrowanie przekazów ustnych) pozwalające ocenić to, jak ludzie reagują na badania archeologiczne oraz jak łączy się to z ich poglądami na kwestie związane z przeszłością.

5) Stworzenie zasobów edukacyjnych pozwalających wprowadzić przedstawicieli wszystkich pokoleń w tematykę dziedzictwa kulturowego.

6) Troska o archiwizację materiałów fotograficznych i filmowych dokumentujących pracę archeologów i codzienne doświadczenia członków wspólnoty związane z projektem. Może to pomóc między innymi w wizualnym uwydatnianiu znaczenia wiedzy społeczności lokalnej przy interpretacji znalezisk i w budowie centrów wystawowych (muzealnych).

7) Kontrolowane przez lokalną wspólnotę czerpanie korzyści z (prze)prowadzonych badań (typu handel ,pamiątkami” i tworzenie wysokojakościowej alternatywy dla typowych czy stereotypowych produktów turystycznych).

Wyznaczonym siedmiu standardom towarzyszy założenie, że kultury są nieustannie tworzone, a tym samym niezmiennie otwarte na pertraktacje, przez co „metodologia współpracy" musi być wysoce elastyczna; stąd zalecana częsta reewaluacja, jako konieczne narzędzie i wyznacznik zmian archeologii wspólnotowej. Ta reewaluacja ma na celu uzyskanie pełniejszego obrazu wspólnot i zwiększenie potencjału badań archeologicznych. Ma ona też sprzyjać „osadzeniu przedmiotowej dyskusji” w „,naukowych ramach” (szczęśliwie będących w dalszym ciągu podstawą archeologii) (za: Truscott 2004; Tully 2007: 176-9).

Aktualne okoliczności wręcz zmuszają archeologów do, zdecydowanie bardziej niż dotychczas, aktywnego reagowanie na potrzeby społeczne oraz na skutki tzw. „demokratyzacji nauki” czy czynienia jej „,nauką obywatelską” (McCormick 2009, Zalewska w druku). Skłania to do czynnego ustosunkowywania się do kwestii „partycypacji” niearcheologów w archeologii. W związku z tym zasadne wydało mi się możliwie proaktywne odniesienie do tych zagadnień. W efekcie stałam się pomysłodawczynią i kierownikiem projektu (w trakcie realizacji), którego celem jest wykazanie, że archeologia może stanowić element prospołecznie zorientowanych badań naukowych, zawierających działania poznawcze, wspólnotowe, edukacyjne i popularyzatorskie. Założyłam, że dzięki tego typu działaniom archeologia może przyczynić się m.in. do wyhamowania, wzmagających się w ciągu ostatniej dekady, aktów destrukcji materialnych reliktów dwudziestowiecznych wydarzeń. 
Prospołeczna, partycypacyjna i „wspólnotowa” archeologia bliskiej przeszłości...

\section{ARCHEOLOGIA JAKO ANTIDOTUM \\ NA ZAPOMNIENIE I WANDALIZM. KU PRZYDROŻNYM LEKCJOM HISTORII \\ NA TEMAT PIERWSZEJ WOJNY ŚWIATOWEJ (1914-2014)12 - STUDIUM PRZYPADKU PROJEKTU W TOKU}

„Setki jeśli nie tysiące zrabowanych i zniszczonych pierwszowojennych grobów i ziemianek pruskich i rosyjskich w Puszczy Bolimowskiej”"13, „marazm bolimowski”14, ,jebać Niemców"15 - te trzy cytaty stanowiły fundamentalne uzasadnienie potrzeby realizacji projektu odnoszącego się do statusu i kondycji śladów pozostałych po walkach z lat 1914-1915 nad Rawką. Za zasadniczy cel projektu uznałam stworzenie zaplecza edukacyjno-popularyzatorskiego w celu upowszechniania odruchów troski o materialne pozostałości po przeszłości (ze szczególnym uwzględnieniem reliktów I wojny światowej). Kolejnym, równie istotnym celem było dążenie do pogłębiania i upowszechnienia wiedzy o złożoności i wyjątkowości wydarzeń sprzed stu lat, w tym faktu, że w walczących w trakcie wielkiej wojny (1914-1918) armiach aż około 1400000 żołnierzy było polskiej narodowości - z czego ok. 500000 zostało zabitych. Efektem realizacji tych celów jest przekazanie lokalnej społeczności oraz innym potencjalnie zainteresowanym odbiorcom przystępnej publikacji pt. Bitwa nad Rawkq i materialne po niej pozostałości oraz stworzenie (Zalewska, Kaliński i Czarnecki 2014) siedmiu tablic informacyjnych, prezentujących treści na temat kontekstu pierwotnego wydarzeń sprzed stu lat, których ślady, pomimo licznych procesów wtórnych (podepozycyjnych i postdepozycyjnych) przetrwały do naszych czasów. Te materialne ślady, wraz z opisami i archiwalnymi ilustracjami składają się na cykl siedmiu Przydrożnych Lekcji Historii. Są to: Bolimów - kościół Świętej Anny - rynek bolimowski (tablica nr 1); cmentarz wojenny w Bolimowskiej Wsi (tablica nr 2); cmentarz wojenny w Wólce Łasieckiej (tablica nr 3); pozostałości niemieckiego zaplecza walk 1914-1915 (tablica nr 4); ślady wojny pozycyjnej i życia w okopach rosyjskich i niemieckich (tablica nr 5); pozostałości kraterów pominowych i wojny podziemnej (tablica nr 6); cmentarz wojenny w Joachimowie Mogiłach (tablica nr 7). Tablice te zostana ustawione w setną rocznicę procesu pierwotnego, w miejscach szczególnie naznaczonych śladami wydarzeń, które miały miejsce między październikiem 1914 i lipcem 1915 roku nad Rawka.

12 Projekt pod tym tytułem ( $\mathrm{nr}$ 00560/2013/TM) realizowany jest aktualnie pod patronatem Instytutu Archeologii i Etnologii Polskiej Akademii Nauk w Warszawie, dzięki dofinansowaniu Fundacji Współpracy Polsko-Niemieckiej. Pomysłodawczynią i kierownikiem projektu jest autorka niniejszego artykułu.

13 Opinia fascynata historii I wojny światowej, poruszonego niszczycielskimi rezultatami nasilających się w sposób radykalny w ostatnim czasie grabieżczych działań poszukiwaczy militariów w Puszczy Bolimowskiej, a zwłaszcza na obszarze ataków gazowych 1914-1915.

14 Określenie zawarte na stronie „Stowarzyszenia Inicjatywa Ziemi Bolimowskiej” charakteryzujące społeczno-polityczne tło zalegania materialnych reliktów I wojny światowej i (nie)pamięci znaczenia wydarzeń sprzed 100 lat, za: www.bolimow.com.pl/news.html (dostęp 1 VIII 2013).

15 Napis na jednym z epitafiów na relatywnie dobrze utrzymanym (abstrahując od stopnia zniszczenia niepoddawanych konserwacji piaskowych płyt nagrobnych) cmentarzu w Bolimowskiej Wsi, gdzie pochowani są obok siebie żołnierze niemieccy, rosyjscy i ci o polsko brzmiących nazwiskach, polegli w latach 1914-1915. 
Motywacją do podjęcia tego typu działań było założenie, że archeologia ma szansę (i obowiązek), by stać się instytucją pamięci kulturowej, która odzyskuje utracone przedmioty i nieużywane informacje z przeszłości, tworząc ważną ścieżkę powrotu od kulturowego zapominania do pamięci kulturowej (Assmann 2008: 98). O ile jednak w przywołanej tu opinii Aleida Assmann odnosi archeologię do odległej przeszłości (distant past), o tyle zamierzenia prezentowanego tu projektu odnoszą się do zagadnień nieodległej w czasie przeszłości. W mojej opinii nie ujmuje im to jednak ani ich archeologicznego charakteru, ani istotności w przestrzeni społecznej. Wręcz przeciwnie, realizacja przywołanego tu jako exemplum projektu, przez osiągnięcie zamierzonych celów, może mieć istotne znaczenie zarówno społeczne, jak i poznawcze/epistemologiczne.

W skali archeologii polskiej i niemieckiej, którym towarzyszy marginalizowanie materialnych pozostałości dwudziestowiecznych konfliktów, potraktowanie jako istotnego przedmiotu badań archeologii materialnych reliktów Wielkiej Wojny może się przyczynić do zdjęcia z nich odium „niewygodnych”, a przez to dotychczas niedostrzeganych, niedocenianych i nieotoczonych troską. Rzadko poddaje się refleksji m.in. obowiązujące dawniej i dziś zasady grobownictwa wojennego na terenie dzisiejszej Polski oraz ich (także materialne) następstwa. $\mathrm{W}$ trakcie realizacji wyjściowych założeń grobownictwa wojennego (w pierwszych dekadach $\mathrm{XX}$ wieku) poległych żołnierzy stron przeciwnych z zasady traktowano tak samo, czyli jak własnych i chowano obok siebie (Pałosz 2012). Następstwa materialne tej bezprecedensowej sytuacji, która na taką skalę nie zaistniała nigdy wcześniej ani tym bardziej nigdy później, czyli w kolejnych ogólnoeuropejskich konfliktach, są wciąż uchwytne. Większość luk w wiedzy na temat wydarzeń wojennych odnosi się do zdarzeń, które miały miejsce na froncie wschodnim w latach 1914-1915. Niewiedza i zapomnienie skutkują wieloma przeoczeniami, niedomówieniami, błędnymi założeniami i nieetycznymi zachowaniami, z którymi konfrontowane są aktualnie materialne pozostałości po wydarzeniach w znaczącym stopniu wypartych z przestrzeni publicznej i z pamięci Polaków, Rosjan i Niemców oraz reszty świata.

Archeologia, co przez realizację projektu staram się dowieść, ma ogromny potencjał czynienia znaczącymi (poznawczo i społecznie) i przez to potencjalnie bliższymi (bo zrozumiałymi) również pozostających in situ śladów działań zbrojnych i różnego typu (re)prezentacji wydarzeń sprzed stu lat. Sprzyja temu otwartość na inspiracje i wnioski płynące zarówno z opisanej wyżej metodologii community archaeology, jak i z archeologii konfliktu (conflict archaeology $y^{16}$ ). Ich aplikacja, w połączeniu z autorską formą działań edukacyjnych i popularyzatorskich (tj. Przydrożnych Lekcji Historii), która jak mam nadzieję odpowiada standardom edukacyjnym krzewienia efektywnego modelu aktywnego uczestnictwa w kulturze, może przyczynić się do korzystnej zmiany w zakresie propagowania postaw opartych na zrozumieniu i szacunku dla materialnych pozostałości przeszłości.

O potrzebie takich działań przekonują między innymi ciągłe akty wandalizmu wobec pochówków i cmentarzy z I wojny na terenie gminy Bolimów, traktowanie leśnych kraterów pominowych jako nielegalnych wysypisk śmieci oraz nasilający się ostatnim czasie proceder tzw. ,czarnej archeologii” (czyli rabunkowego, grabieżczego traktowania obiektów z I wojny

16 Od dekady można zaobserwować co najmniej dwutorowy rozwój subdyscypliny archeologii określanej mianem conflict archaeology, por. Scott 2011; Saunders 2004. 
światowej takich jak transzeje, ziemianki, a nawet pochówki żołnierzy). Takie zachowania kontrastują z aktualnym stosunkiem do materialnych śladów Wielkiej Wojny na innych odcinkach byłego frontu, zwłaszcza zachodniego. Otaczaniu ich troska, poddawaniu konserwacji czy muzealizacji sprzyja opinia (coraz zresztą powszechniejsza wśród archeologów brytyjskich, francuskich, belgijskich czy włoskich), że ,żaden inny przedmiot badań archeologii nie jest tak poruszająco antropologiczny jak Wielka Wojna i inne konflikty XX wieku" (Saunders 2012) ${ }^{17}$. Choć brzmi to niepokojąco, warto z powagą potraktować diagnozę, że nasza refleksja nad tym, co z wojen pozostało, ma potencjał łączenia różnoczasowych pokoleń i narodów oraz różnych podmiotów, między innymi naukowców, studentów, osoby zwiedzające pola bitewne oraz wszystkich, którzy pragną zrozumieć straty i wysiłki ludzkie, składające się na tworzenie świata, w którym żyjemy.

Na zachodzie Europy słusznie i szeroko eksponowany jest fakt, że archeologia konfliktu, w tym archeologia pierwszej wojny światowej ma istotny i znaczący wpływ na kształtowanie świadomości społecznej. Tymczasem na terenie dzisiejszej Polski aktualizowanie reliktów i „krajobrazów upamiętnień” Niemców, Rosjan i Polaków, którzy tu walczyli, jest problematyczne. Na przykład podejmowane dotychczas w gminie Bolimów próby mające na celu uchronienie przed zniszczeniem materialnych reliktów Wielkiej Wojny były mało skuteczne (zob. Zalewska 2013a: 41-42). Na obszarze, który sto lat temu stanowił jedną z kluczowych scen teatru pierwszowojennego (ustanawiając między innymi właśnie w rejonie Rawki i Bzury obszar inicjacji użycia broni chemicznej) dziś zapanował „marazm” poznawczy i kulturowy. Analiza przyczyn takiej sytuacji wymaga odrębnych badań, a próba zmierzenia się z nimi była możliwa wyłącznie dzięki samozaparciu i finansowemu wsparciu Fundacji Współpracy Polsko-Niemieckiej, gdyż władze lokalne dopiero nabierają przekonania o istotności również kulturowego (historycznego) potencjału krajobrazu, w którym funkcjonują.

Istotnym potencjalnym następstwem realizacji projektu pt. Archeologia jako antidotum na zapomnienie $i$ wandalizm jest możliwość przekucia tego co doraźne (zwłaszcza jubileuszowego zainteresowania Wielką Wojna) w trwałe pozytywne zmiany w kwestii świadomości i wrażliwości historycznej. Może to zwiększyć szanse na (prze)trwanie pozostałych do naszych czasów reliktów. Jednocześnie zakładam, że realizacja z czynnym udziałem archeologii autorskiego programu Przydrożne Lekcje Historii (na aktualnym etapie - w odniesieniu do pierwszej wojny światowej i jej następstw) może przyczynić się do uczynienia przeszłości bliższą, istotniejszą, pouczającą, a przyszłości bardziej refleksyjną i zainteresowaną fenomenem trwania ludzi (w tym pamięci o tych, którzy odeszli) obok rzeczy, przez rzeczy i dzięki rzeczom.

Na aktualnym etapie można stwierdzić, że w ramach projektu Archeologia jako antidotum na zapomnienie $i$ wandalizm podjęte zostały wszelkie możliwe działania.

17 Co szczególnie ciekawe, autor tej opinii Nicholas J. Saunders (2007, 2012), zajmujący się zwłaszcza archeologią pierwszej wojny światowej, podkreśla też, że za archeologię warto uznać również odkładające się dziś, tj. na naszych oczach, warstwy - nie tylko w postaci fizycznych pozostałości zniszczeń, lecz również w formie nowych i odnawianych pomników oraz krajobrazów upamiętnienia, nowych muzeologicznych nawiązań do konfliktu, medialnej polityki prezentacji wojny, koncepcji na temat dziedzictwa wojennego oraz rozwijającego się przemysłu turystyki związanej z miejscami konfliktów. 
Działania te przyczyniły się bądź przyczyniać się będą do:

- pogłębienia wiedzy na temat statusu i potencjału materialnych pozostałości po Wielkiej Wojnie wśród ludności lokalnej (stąd pomysł realizacji wykładów otwartych np. Pierwsza wojna światowa nad Rawka i Bzurq. TO byto właśnie TU!, prelekcji np. Archeologia pierwszej wojny światowej oraz moderowanych dyskusji np. (Nie)pamięć ludzka versus pamięć materii) (szczegóły vide http://archeopressja.wordpress.com/przydrozne-lekcje-historii);

- opracowania w paradygmacie ,archeologii wspólnotowej” prototypowych rozwiązań, modeli pomocy dydaktycznych przydatnych w przywracaniu pamięci o wydarzeniach sprzed stu lat, wprost odnoszących się do materialnych nośników wiedzy znaczeń i pamięci o Wielkiej Wojnie;

- rozpoznania nastawienia do i stanu wiedzy na temat materialnych pozostałości po konflikcie sprzed stu lat wśród lokalnej ludności oraz wdrożenie dostosowanych do tego praktyk uspołeczniania pobudzających motywację i wolę troski o te pozostałości (stąd m.in. próba wspólnotowych działań mających na celu delimitację i zabezpieczenie najbardziej narażonych na zniszczenie obiektów, w tym skierowane do lokalnej młodzieży warsztaty pt. Troska o cmentarz w Bolimowskiej Wsi-upamiętnianie poprzez dotykanie, dokumentowanie i refleksje).

UWAGI KOŃCOWE:

PROCES SPOEECZNEGO OBIEGU WIEDZY ARCHEOLOGICZNEJ (IV) JAKO INTEGRALNY ELEMENT PROCESU BADAWCZEGO OSADZONY W NAUKOWYCH RAMACH

Dla badaczy fundamentalne jest uświadomienie sobie, że badania przeszłości nie odnosi się do przeszłości samej w sobie, ale do teraźniejszości samej w sobie. Zwłaszcza dane archeologiczne, obecne zawsze tu, razem z nami - stanowią unaocznienie/uobecnienie faktu, że obserwacje, które możemy poczynić, nie mają innego sensu jak tylko tu i teraz, w relacji do teraźniejszości. Archeologia nie jest nauką, która pozwala studiować przeszłość bezpośrednio, nie jest też działalnością, której jedyna „moc” wypływa z „odkrywania przeszłości”. Wprost przeciwnie, znaczenie i rola archeologii realizuje się w dookreślaniu wpływu, który mają na przeszłość (i na teraźniejszość) rzeczy znalezione tu i teraz. Czyni to całą archeologię archeologią teraźniejszości, a zagadnienia w jej ramach występujące (stopniowo coraz wnikliwiej analizowane) obarcza aktualnymi problemami natury społecznej.

Zakres, w jakim różne wątki (z) przeszłości pojawiają się bądź pojawiać się będą w kontekście badań archeologicznych, zależny jest od wielu czynników wynikających z teraźniejszości, w tym od zróżnicowanego charakteru odniesień do kwestii przynależności narodowej, religijnej, politycznej gospodarzy i najeźdźców, ofiar i oprawców, z których działaniami, przez ich materialne korelaty, mamy do czynienia po wielu latach od ich pierwotnego zaistnienia. Jest to szczególnie czytelne w odniesieniu do problematyki, z którą mierzy się archeolog 
współczesności. W jej ramach w sposób szczególny następstwa interakcji z wydobytymi z ziemi sfragmentaryzowanymi śladami tego, co tylko pozornie minione, zależne są od stopnia, w jakim dana wspólnota (pamięci, interpretacyjna itp.), w której rozgrywają się badania archeologiczne, jest w sensie bezpośrednim/osobistym związana z odkrywanymi śladami materialnymi minionych wydarzeń zarówno na poziomie indywidualnym, jak i grupowym. Nie jest jednak tak, że wszystko, co jest materialną pozostałością wydarzeń nieodległych w czasie, stanowi clou, a tym samym przedmiot badań archeologii współczesności. Będzie nim jedynie to, w stosunku do czego postawione zostaną archeologiczne pytania badawcze, przy czym jako równie istotne warto postrzegać „pierwotne” (I) i „wtórne” (II-IV) powody składające się na podstawę do zadania tych pytań. Wszystkie one mają wpływ na ewentualną bliskości materialnych pozostałości z przeszłości.

Przeszłość (w tym odnosząca się do niej archeologia) jest bliska nie tylko dlatego, że jest „teraz” i na bieżąco, ale ponieważ nie jest zamknięta i to zarówno w sensie jej interpretacji (poznawczej, dowodowej itp.), jak i w sensie jej etycznego i emocjonalnego wpływu na teraźniejszość. Ta konstatacja skłania do powrotu do pytania (wyartykułowanego w przypisie 5) o to, czy „oddziaływanie na sferę emocji człowieka” przesądza o „,aintelektualnym charakterze odbioru". Odpowiedź postrzegam jako złożoną. Ograniczam ją do domeny archeologii, a nawet jedynie do obserwacji własnych, co pozbawia ją znamion sądu nomograficznego. Owszem również w kontekście archeologii mamy do czynienia ze zjawiskiem „,aintelektualnym”, jeśli pominięty zostaje etap uwrażliwiania potencjalnego uczestnika na specyfikę materialnych pozostałości po przeszłości oraz jeśli uczestnik nie zyska merytorycznego zaplecza umożliwiającego mu samodzielną refleksję. Wówczas będzie to rodzaj uczestnictwa powierzchownego, które analogicznie do partycypacji, niewymagających przygotowania w zakresie wiedzy o kulturze czy estetyce, pozostanie aintelektualne (powołuję się tu na trafną diagnozę A. Pałubickiej 2013). W związku z tym tak istotny wydaje się czynny udział archeologów w działaniach edukacyjnych i prewencyjnych. Nie sądzę natomiast, by o ,aintelektualnym charakterze" działań wspólnotowych/partycypacyjnych przesądzać miało to, że właśnie emocjonalne zaangażowanie sprzyja temu, że efekty współdziałania czy współuczestnictwa będą „natychmiastowe i zapamiętane” (vide Pałubicka 2013: 201). Związane z wytwarzaniem nowych pragnień, wyobrażeń i odczuć skupienie się na organizowaniu przeżyć może przynieść właściwe skutki, ,jeśli owe przeżycia poddane zostaną werbalizacji”, co uczyni je „wartościami”"18. Jednak jeśli owe przeżycia będą „tylko emocjami”, jeśli nie zostaną „przełożone" na pojęcia, to utkną na aintelektualnym, ateoretycznym, apoznawczym poziomie ${ }^{19}$.

18 Warto tu przywołać opinię Alfredo Gonzáleza-Ruibala (2008: 251), że archeologia powinna wypalać się w pamięci odbiorców, a przynajmniej przywoływać wrażenie żywej obecności przeszłych wydarzeń.

19 Działania takie wiążą się ze współczesną zmianą modelu partycypacji w kulturze z ,intelektualnego” na „przeżyciowy”. Diagnoza ta jest o tyle kluczowa, że modelowi „partycypacji przeżyciowej” (w którym faktycznie „wywiera się wpływ na stan emocji odbiorców wydarzeń kulturowych” przez „przekształcanie dotychczasowych odbiorców w aktywnych uczestników zdarzenia kulturowego” za: Pałubicka 2013: 198-199) zarzuca się „sprzeniewierzenie się gramatyce kultury europejskiej w dobie postmodernistycznej kultury”. Jest to w pełni uzasadnione wówczas, gdy wraz ,z interaktywnością”, z którą „łączy się konieczność wywoływania sytuacji zaangażowania odbiorców w realizację zadania" archeolog nie zdoła zainicjować potrzeby kształtowania „krytycznego namysłu” nad tym zadaniem. 
O klęsce wyjściowych założeń (na przykład archeologii wspólnotowej) trzeba będzie mówić wówczas, gdy jednostka (za)angażowana w badania archeologiczne pozostanie zainteresowana tylko tym, co osobiście przeżywa ${ }^{20}$.

Kwestie te, choć z obranej tu perspektywy kluczowe dla przyszłości badań nad materialnymi pozostałościami przeszłości, są w Polsce nieustannie zaniedbywane. Z tego powodu właśnie postuluję, by proces uspołeczniania archeologii (odnoszący się do społecznego obiegu wiedzy archeologicznej oraz do ról i funkcji łączonych z materialnymi pozostałościami z przeszłości) (domena IV) traktować jako domenę równie istotną w myśleniu $\mathrm{o}$ archeologii co pozostałe (I-III). Ten istotny $\mathrm{i}$ integralnie związany z akademicką praktyką archeologiczną element ma (w coraz większej mierze) charakter sprawczy, co niesie ze sobą zarówno potencjalne korzyści (na przykład przejawiające się w postrzeganiu archeologii jako istotnej i niezbędnej dyscypliny naukowej czy poszerzaniu chronologicznego zakresu badań archeologii), jak i straty (na przykład wynikające $z$ trywializacji i utowarowiania wiedzy archeologicznej, zob. Little 2002; Pawleta 2012: 1129-1138).

Wydaje mi się, że przez kompleksową (I-IV) analizę przyczyn i następstw konkretnych, szkodliwych społecznie praktyk i nadużyć rozgrywających się w kontekście materialnych pozostałości po przeszłości, w tym archeologii, możliwe jest inicjowanie właściwych/ skutecznych środków zaradczych wobec niedostatków wiedzy (między innymi na temat konfliktów, z których śladami i następstwami konfrontuje nas teraźniejszość) oraz wobec trywializowania znaczenia trudnej przeszłości. Dążenia do zerwania z wynikającym w dużej mierze z pasywności archeologów poczuciem przyzwolenia na nadużycia dotyczące materialnych pozostałości przeszłości powinny się przejawiać w konkretnych działaniach i jak mam nadzieję w idących w ślad za nimi przewartościowaniach sprzyjających wyhamowaniu postępującego procesu deprecjacji ról i znaczeń oraz statusu (między innymi przez ich „odrzeczowienie”) materialnego dziedzictwa. Musi im towarzyszyć dyskusja zarówno na temat potencjału dyskursu archeologicznego w przestrzeni publicznej, jak i na temat radykalnie się aktualnie zmieniającej specyfiki i tożsamości archeologii.

Są jednak aspekty, w przypadku których archeologia wypowiedzieć się nie zdoła. Nie sposób na przykład w sposób wyczerpujący uchwycić w terminach archeologicznych faktu, że poczucie bliskości z materialnymi pozostałościami przeszłości wynika nie tyle z ,krótkiej chronologii” (czyli nieodległego w czasie procesu pierwotnego), ile z ich pełniejszego zrozumienia i docenienia (także tego wynikającego z możliwości wykorzystania tych pozostałości dla bieżących, pozapoznawczych celów) (por. Domańska 2012). Z tego wynika prośba o włączenie się do dyskusji z archeologami, o archeologach, o archeologii oraz o materialnych pozostałościach z przeszłości przedstawicieli innych dyscyplin, w tym socjologów. Zakładam, że taka kompleksowa/wspólnotowa refleksja nad archeologią, odnosząca się do wszystkich czterech procesów/domen (I-IV) daje podstawy do refleksji nad (współ)trwaniem ludzi i rzeczy.

Jednocześnie archeologia bliskiej przeszlości może być postrzegana jako krok w kierunku stworzenia kompleksowej, wielodyscyplinarnej czy nawet postdyscyplinarnej

20 Taka jednostka/uczestnik odrzuci przez to trzecioosobowy dystans wobec świata, niezbędny w uczestniczeniu w sferze publicznej i obowiązujący w niej sposób myślenia oparty na racjonalnej argumentacji, oddając się sferze własnych przeżyć (zob. Pałubicka 2013: 199-200). 
taktyki myślenia na temat specyfiki i sensów trwania wspólnot ludzkich oraz wspólnoty ludzi i rzeczy w czasie. Za istotny element tej taktyki uznać można niezbędność odniesień do specyfiki „czasu archeologicznego”, który nie zatrzymuje się w momencie, gdy ustają procesy depozycyjne (pierwotne), lecz sprawia, że materia pozostałości (matiere des vestiges) cały czas pracuje/trwa i działa (zob. Olivier 2008: 39, por. też Lucas 2010). Materialne pozostałości przeszłości są „,pochłaniane” przez inne środowisko, w którym utrzymuja/podtrzymują nieuchwytną pamięć innych czasów. Pozostałości te mogą być traktowane jako pamięć aktywna w teraźniejszości, lecz czego byśmy nie robili - te pozostałości przeszłości będą się starzeć i zmieniać na ich własnych zasadach i we właściwy dla nich sposób. Jednocześnie jednak będą z nami pozostawały oraz nas prowokowały w naszej wspólnej teraźniejszości, przez co mogą stawać się nam bliskie.

\section{BIBLIOGRAFIA}

Assmann, Aleida 2008. Canon and Archive, w: Astrid Erll (red.), Media and Cultural Memory. Berlin - New York, s. 97-107.

Buchli, Victor i Lucas Gavin (red.) 2001. Archaeologies of the contemporary past. London - New York: Routledge.

Czarnocka, Małgorzata 2007. O zależności nauki od kultury, w: Alina Motycka (red.), Wiedza a kultura, Warszawa: Wydawnictwo IFiS PAN, s. 82-106

Domańska, Ewa 2012. Historia egzystencjalna. Krytyczne studium narratywistyki i humanistyki zaangażowanej, Warszawa: Wydawnictwo Naukowe PWN.

González-Ruibal, Alfredo 2008. Time to Destroy. An Archaeology of Supermodernity, „Current Anthropology" 49(2): 247-279.

Kobyliński, Zbigniew 2009. Archeologia wobec wyzwań współczesności, w: Michał Brzostowicz (red.), Archeologia polska i jej czasy, Poznań: Wydawnictwo Poznańskiego Towarzystwa Przyjaciół Nauk, s. 103-131.

Kola, Andrzej 2005. Archeologia zbrodni. Oficerowie polscy na cmentarzu ofiar NKWD $w$ Charkowie, Torun: Wydawnictwo Naukowe UMK.

Little, Barbara J. (red.) 2002. Public Benefits of Archaeology, Gainesville: University Press of Florida.

Marshall, Yvonne (red.) 2002. Community archaeology, „,World Archaeology” 34(2): 211-403.

McCormick Sabrina 2009. From ,,politico-scientists” to democratizing science movements: the changing climate of citizens and science, „Organization \& Environment” 2009, 22, 1: 34-51.

Olivier, Laurent 2008. Le sombre abime du temps: memoire et archeologie. Paris: Seuil.

Olsen, Bjørnar 2010. In Defence of Things: Archaeology and the Onthology of Objects. Lanham: AltaMira Press.

Olsen, Bjørnar, Michael Shanks, Timothy Webmoor i Christopher Witmore 2012. Archaeology. The Discipline of Things. Berkeley, Los Angeles, London: University of California Press.

Pałosz, Jerzy 2012. Śmiercia złaczeni. O cmentarzach z I wojny światowej na terenach Królestwa Polskiego administrowanych przez Austro-Węgry, Kraków: Libron. 
Pałubicka, Anna 2013. Gramatyka kultury europejskiej, Poznań: Epigram.

Pawleta, Michał 2012. Obrazy przeszłości w narracjach współczesności, w: Stanisław Tabaczyński, Dorota Cyngot, Arkadiusz Marciniak i Anna Zalewska (red.), Przeszłość społeczna. Próba konceptualizacji. Poznań: Wydawnictwo Poznańskie, s. 1124-1140.

Saunders, Nicholas J. 2004. Material culture and conflict: the Great War, 1914-2003, w: Nicholas J. Saunders (red.), Matters of Conflict: Material Culture, Memory and the First World War. London: Routledge, s. 5-25.

Saunders, Nicholas J. 2007. Killing Time. Archaeology and First World War. Stroud: The History Press.

Saunders, Nicholas J. 2012. Introduction: Engaging the Materialities of Twentieth and Twentyfirst Century Conflict, w: Nicholas J. Saunders (red.), Beyond the Dead Horizon. Studies in Modern Conflict Archaeology, Oxford and Oakville: Oxbow Books, s. 8-14.

Schiffer, Michael B., Gould Richard A. (red.) 1981. Modern Material Culture. The Archaeology of Us. London: Academic Press.

Scott, Douglas, Andrew P. McFeaters 2011. The Archaeology of Historic Battlefields: A History and Theoretical Development in Conflict Archaeology, ,Journal of Archaeological Research" 19: 103-132.

Simpson, Faye 2008. Community Archaeology Under Scrutiny, „Conservation \& Management of Archaeological Sites" 10 (1): 3-16.

Simpson, Faye, Williams Howard 2008. Evaluating Community Archaeology in the UK, „Public Archaeology” 7 (2), Summer: 69-90.

Szpociński, Andrzej 2009. Wizualizacja pamięci społecznej, w: Andrzej Szpociński (red.), Pamięć zbiorowa jako czynnik integracji i źródło konfliktów, Warszawa: Scholar, s. 227-236.

Tabaczyński, Stanisław 1987. Archeologia średniowieczna: problemy, źródła, metody, cele badawcze. Warszawa: Ossolineum.

Tilley, Christopher 1989. Archaeology as socio-political action in the present, w: Valeria Pinsky i Alison Wylie (red.), Critical traditions in contemporary archaeology, Cambridge: Cambridge University Press, s. 104-116.

Truscott, Marilyn C. 2004. Is community archaeology the future? An examination of community based archaeology in Australia today and its origins, „The Artefact” 27: 29-35.

Tully, Gemma 2007. Community archaeology: general methods and standards of practice, „Public Archaeology” 6 (3): 155-187.

Wylie, Alison 1995. Alternative histories. Epistemic disunity and political integrity, w: Peter

R. Schmidt i Thomas C. Patterson (red.), Making alternative histories, Santa Fe: School of American Research Press, s. 255-272.

Zalewska, Anna (red.) 2003. Victor Buchli and Gavin Lucas. Archaeologies of Contemporary Past, „Archeologia Polski” 48: 252-275.

Zalewska, Anna 2013a. Relevant and Applicable Archaeology. The Material Remains of the First World War: between „Foundational” and „Biographical” Memory, between „Black Archaeology” and „Conflict Archaeology”, „Sprawozdania Archeologiczne” 65: 9-49. 
Prospołeczna, partycypacyjna i „wspólnotowa” archeologia bliskiej przeszłości...

Zalewska, Anna 2013b. Archäologie und soziales Gedächtnis: Zwischen der Wahl der Vergangeheit Und der Last der Vergangenheit, w: Hans H. Hahn, i Robert Traba (red.), Deutsch-Polnische Erinnerungsorte, Reflexionen, München - Wien - Zürich: Ferdinand Schöningh, s. 221-245.

Zalewska, Anna, Archeologia (we) współczesności: archeologia współczesnej przeszłościaktualny zarys i przedmiot badań, w: Archeologia wspótczesności. Archeologia konfliktu. Archeologia martyrologii XX wieku (w druku).

Zalewska, Anna, Stanisław Kaliński i Jacek Czarnecki 2014. Bitwa nad Rawka i materialne po niej pozostałości. Warszawa.

\section{SOCIAL, PARTICIPATORY AND "COMMUNITY" ARCHEOLOGY OF RECENT PAST AS A WAY OF CONSTRUING THE MEANING OF SUBSISTANCE (OF PEOPLE AND THINGS)} AND AN ANTIDOTE TO DEFICIENCIES OF KNOWLEDGE TRANSVITALISATION OF THE PAST

In an attempt to demonstrate the value and specificity of the archaeology of the close past (which only to some extent corresponds to determinations already functioning in the scientific discourse, such as the archaeology of modernity, historical archaeology, or the archaeology of us), I highlight in this article the areas where archaeology somewhat naturally intertwines with anthropological and sociological reflection. Beside several observations pertaining to general archaeological theory I provide some insights into revealing the entanglement between people and things and dependence of people on things. Subsequently, I present some arguments that archaeology (seen simultaneously as the way of obtaining the thorough knowledge of the distant and near past and as the social practice) is fundamentally tied to the present. My observations in terms of the relations between society and archaeology have been inspired by so-called community archaeology, whose premise is to methodologically encourage its treatment as a directive, also in the Polish context. In the subsequent part of the article, as the exemplification of theoretical assumptions, the authoring program titled Roadside Lessons of History is presented. Trough the implementation of that program I am trying to prove social usefulness and efficacy of material remains of the past, and of archeology. I also confront particular social contexts in which the material remains of the Great War function; of which one (the region of Rawka and Bzura Rivers) is characterised by the fact that the relatively close proximity of the material remains is only really a matter of chronology; whereas in the other (Flanders Fields in Belgium), aside from the 'youth' of the record, this closeness/proximity is also a matter of various processes that deepen the connection between the present and the past. Finally, in my conclusions I reflect on the validity of treating the social circulation of archaeological knowledge as an integral element of the archaeological practice itself, in a process which I propose to describe as socialisation of archaeology within which the significant role is played among other, by the podepositional processes.

Key words: processes of the socialisation of archaeology, social circulation of archaeological knowledge, archaeology of the recent (close) past, community archaeology 